\title{
Seedbank characteristics of a Nebraska sandhills prairie
}

\author{
CLAUDIO J. PÉREZ, STEVEN S. WALLER, LOWELL E. MOSER, JAMES L. STUBBENDIECK, AND ALLEN A. STEUTER
}

\begin{abstract}
Authors are range researcher at Instituto de Investigaciones Agropecuarias, Centro Regional de Investigación Kampenaike, P.O. Box 277, C.nta Arenas, Chile; professors, Department of Agronomy, University of Nebraska-Lincoln, Lincoln, Neb. 68583; and science director, The Nature Conservancy, Niobrara Valley Preserve, Route 1, Johnstown, Neb. 69214. At the time of the research, the senior author was a graduate research assistant, Department of Agronomy.
\end{abstract}

\section{Abstract}

Evaluating seedhank ecology is critical for understanding plant community development and successional patterns and for identifying factors regulating population dynamics. The relationships among seedbank composition, seedbank depth, seed dormancy, and vegetative expression were evaluated for a range site on a Valentine fine sand soil (mixed, mesic Typic Ustipsamments) in the Sandhills Prairie. Twenty soil samples were collected at each of 2 depths $(0$ to 5,15 to $20 \mathrm{~cm}$ ) in early June 1990 and 1991 from 12 macroplots $(32 \times 32 \mathrm{~m})$ representing 3 range condition classes. A seed extraction and germination trial was conducted to determine the diversity, size, and germinability of the persistent seedbank. Seedling emergence was counted in a greenhouse, with and without a 14-day prechilling $\left(3\right.$ to $\left.5^{\circ} \mathrm{C}\right)$ stratification treatment, to characterize seedbank dormancy. Fourteen grass species, 17 forb species, and Schweinitz flatsedge (Cyperus schweinitzii Torr.) were identified in the seed bank. Two additional genera (Carex and Euphorbia) also occurred in the seedbank. Only 10 species occurred in 8 or more macroplots in both years. Aboveground botanical composition was not correlated with $(P>0.10)$ seedbank species composition. More germinable seeds occurred in the 0 to $5 \mathrm{~cm}$ depth $(P<0.01)$ than the 15 to 20 cm depth. Also, the species diversity and seed number were greater in the shallower depth. Germination percentage was low for all types of vegetation. Lambsquarters (Chenopodium album L.) and annual eriogonum (Eriogonum annuum Nutt.) had the largest seedbanks, but germination was less than $6 \%$. Sand dropseed [Sporobolus cryptandrus (Torr.) Gray] and sand lovegrass [Eragrostis trichodes (Nutt.) Wood] were the most abundant perennial grasses and accounted for about $60 \%$ of the germinated seeds. Prechilling increased seedling emergence of grasses $(P<0.01)$, forbs $(P<0.01)$, and grass-like species $(P<0.01)$. Perennial grasses emerged first, forbs later, and grasslike species exhibited a bimodal emergence pattern. Based on germination percentage and emergence data, sand dropseed has the potential to colonize openings in the Sandhills prairie, possibly to the exclusion of many annuals occurring in the seedbank.

Key Words: germination percentage, lambsquarters, marestail, sand dropseed, sand lovegrass, secondary succession

\footnotetext{
The authors wish to thank the anonymous reviewers for their reviews which improved this manuscript. Mention of a trade name in this paper does not constitute a recommendation by the University of Nebraska nor does it imply registration under FIFRA. This manuscript has been assigned Journal Series No. 10674 Agricultural Research Division, University of Nebraska.

Manuscript accepted 24 Feb. 1997
}

\section{Resumen}

Evaluar los bancos de semillas en el suelo es muy importante para entender el desarrollo, los patrones sucesionales de las comunidades vegetales y para identificar los factores que regulan las dinámicas poblacionales de éstas. Las relaciones entre la composición, la profundidad de los bancos de semillas, la dormancia de las semillas y la expresión de la vegetación sobre la superficie fue evaluada para un sitio de pastizal localizado en un suelo fino arenoso tipo Valentine (mixed, mesic, Typic Ustipsamments) en Sandhills Prairie, Nebraska. En Junio de 1990 y 1991, se recolectaron 20 muestras de suelo a dos diferentes profundidades $(0$ a 5 y 15 a $20 \mathrm{~cm}$ ) en 12 parcelas $(32 \times 32 \mathrm{~m})$ que representaban 3 clases de sitio de pastizal. Para determinar la diversidad, tamaño y germinabilidad del banco de semillas, se realizó un ensayo de extracción y germinación de semillas. Para caracterizar la dormancia de las semillas, se cuantificó la emergencia de las plántulas en invernadero con un tratamiento de estratificación, con y sin un período de 14 días de frío $\left(3\right.$ a $\left.5^{\circ} \mathrm{C}\right)$. Catorce especies de zacate, 17 especies de hierbas y una ciperacea (Cyperus schweinitzii Torr.) fueron identificadas en el banco de germoplasma. Además, fueron identificados dos géneros adicionales (Carex y Euphorbia) en el banco de germoplasma. En ambos años, solo 10 especies se presentaron en 8 o más parcelas. La composición botánica sobre la superficie no tuvo correlación $(P>0.10)$ con la composición del banco de germoplasma. Un mayor número de semillas viables se presentaron a la produndidad de 0 a $5 \mathrm{~cm}$ de profundidad ( $P<0.01$ ) que a 15 a $20 \mathrm{~cm}$ de profundidad. Aolemás, la diversidad de especies y el número de semillas fue mayor en el perfil de menor profundidad. El porcentaje de germinación fue bajo para todos los tipos vegetacionales. Chenopodium album L. y Eriogonum annuum Nutt. tuvieron la mayor participación en el banco de semillas, pero la germinación del mismo fue menos que el 6\%. Zacatón arenoso ([Sporobolus cryptandrus (Torr.) Gray] y Zacate de amor arenoso [Eragrostis trichodes (Nutt.) Wood] fuerun los zacates perennes más abundantes y participaron con alrededor del $60 \%$ de las semillas germinadas. El tratamiento de frío aumentó; la emergencia de plántulas de zacates $(P<0.01)$, hierbas $(P<0.01)$, y ciperáceas $(P<$ 0.01). Los zacates perennes emergieron primero, luego las hierbas y las ciperáceas presentaron un patrón de emergecia bimodal. Basándose en los porcentajes de germinación y en los datos de emergencia, el zacatón arenoso tiene el potencial de colonizar sitios abiertos en las Sandhills Prairies, probablemente debido a la exclusión de muchas especies anuales que se presentan en el banco de germoplasma. 
A seedbank is an aggregation of ungerminated seeds capable of replacing mature annual or perennial plants (Baker 1989). Understanding seedbank ecology is critical for developing theory on community development, structure, and function. The dynamics of the seedbank determine the ability of a community to persist. The seedbank may contain diverse species and genotypes that provide substantial flexibility for potential community changes (Leck et al. 1989). On rangelands, seeds often occur as a thin, discontinuous layer on or near the soil surface. The distribution of this layer is influenced by local micro-topography and the location of plant litter deposition (Young 1988). The seedbank is a major contributor to vegetative colonization patterns observed in disturbed areas.

Seedbank dynamics of the Nebraska Sandhills are not well understood, particularly as they relate to vegetative expression in plant communities and colonization of bare areas following disturbance. The Nebraska Sandhills are a very fragile ecosystem with bareground and litter accounting for approximately $90 \%$ of the basal cover on the sands range site (Pérez 1991). The objectives of this study were to: 1) determine the persistent seedbank (Thompson and Grime 1979) diversity and size, seed dormancy and germination, and seedling emergence; 2) determine the effect of botanical composition on the persistent seedbank, and 3) compare a shallower, persistent seedbank $(0$ to $5 \mathrm{~cm})$ with a deeper seedbank $(15$ to $20 \mathrm{~cm})$.

\section{Materials and Methods}

\section{Study Area}

The study was conducted in 1990 and 1991 at the University of Nebraska-Lincoln (UNL) Gudmundsen Sandhills Laboratory (GSL) $(5,260 \mathrm{ha})$ near Whitman, Nebraska (approximately $42^{\circ}$ $05^{\prime} \mathrm{N}$ and $101^{\circ} 26^{\prime} \mathrm{W}$ ) on a Valentine fine sand (mixed, mesic Typic Ustipsamments; sands range site). The experimental area is $1,049 \mathrm{~m}$ above sea level. The topography is characteristic of the Sandhills rangeland, with undulating grass-stabilized dunes of eolian sand and interdunal valleys (Kuzila 1990). The average annual precipitation is $460 \mathrm{~mm}$, approximately $85 \%$ of which occurs during the growing season (April to September). Accumulative evapotranspiration reaches $2,014 \mathrm{~mm} /$ year, resulting in a negative balance between precipitation and evapotranspiration (USDA-SCS 1977).

Macroplots (considered experimental units) of approximately $1,000 \mathrm{~m}^{2}$ each $(32 \times 32 \mathrm{~m})$, representing 3 range condition classes (excellent, good, and fair) were replicated 4 times on sands range sites. The minimum distance between macroplots was 0.4 $\mathrm{km}$ and the maximum was $6.5 \mathrm{~km}$. Range condition was determined in mid-August 1990 and 1991 by estimating the weight of individual species (Nichols et al. 1984). To adjust weight estimates, aboveground plant biomass was clipped to a stubble height of $2.5 \mathrm{~cm}$ in 4 quadrats $\left(0.25 \mathrm{~m}^{2}\right)$ in each macroplot and separated by species into current year's growth. Samples were dried in a forced-air oven at $70^{\circ} \mathrm{C}$ until a constant weight was obtained. The botanical composition of each macroplot was calculated from basal cover, determined in early June 1990 and 1991 using the modified step point method (Owensby 1973). One hundred points were read in each macroplot (three $30-\mathrm{m}$, randomly located transects).

\section{Seedbank Sampling}

The sampling strategy was designed for the persistent seed bank (Thompson and Grime 1979). Since 99\% of the seeds entered the seed rain after June in a similar Sandhills Prairie site (Potvin 1988), the sampling date excluded most of the current year's seed production from the persistent seedbank. Twenty soil samples were randomly collected at each of 2 depths ( 0 to 5 and 15 to $20 \mathrm{~cm}$ ) within each of the 12 macroplots-in June 1990 and 1991. A 2-m exterior boundary was excluded from sampling within each macroplot. An area $12 \times 12 \mathrm{~cm}$ was excavated to a depth of $30 \mathrm{~cm}$. The core was laid horizontally; litter removed form the surface, and the 0 to 5 and 15 to $20 \mathrm{~cm}$ segments extracted. Each sample consisted of about $1 \mathrm{~kg}\left(700 \mathrm{~cm}^{3}\right)$ of soil. The 20 samples for each depth within a macroplot were composited, dried at air temperature and separated into 8 subsamples. Four macroplot subsamples were assigned to the seed extraction/germination trial and 4 were used in the greenhouse emergence trial.

\section{Seed Extraction/Germination Trial}

The total seedbank (germinable and nongerminable) was estimated using a two-phased soil organic matter (OM) extraction and germination technique (Kropac 1966, Roberts 1981). Duplicate samples $(0.25 \mathrm{~kg})$ were randomly selected from each macroplot subsample. Each duplicate was placed in a $1,000 \mathrm{ml}$ Erlenmeyer flask and mixed with $250 \mathrm{ml}$ of distilled water containing $6.25 \mathrm{~g} \mathrm{CALGON}^{\mathrm{TM}}$. After $3 \mathrm{~min}$ at $400 \mathrm{rpm}$ in a BURRELL $^{\mathrm{R}}$ Model 75 wrist action shaker, the slurry was poured through a sieve $(500 \mu \mathrm{m})$. The retained $\mathrm{OM}$ was rinsed with distilled water and poured into a petri dish ( 1 petri dish/flask). After the material was air dried at room temperature, seeds were separated manually from the OM, identified to genus and to species when possible, counted by species (or genus), and placed in a petri dish lined with filter paper ( 1 petri dish/flask). A 21 day germination test was then conducted $\left(20^{\circ} \mathrm{C}\right.$ for 16 hours to $30^{\circ} \mathrm{C}$ for 8 hours). Temperature and light variables were selected to accommodate a broad array of the anticipated native species (Maxon 1993). Seeds were considered germinated when the radicle attained a length of $1 \mathrm{~mm}$.

Following the 21-day germination period, the petri dishes were placed in a refrigerator for 4 weeks at 3 to $5^{\circ} \mathrm{C}$ (McDonald et al. 1992) to assess seed dormancy. Afterwards, the petri dishes were watered with a $600 \mathrm{mg} / \mathrm{kg}$-solution of Gibberellic Acid (SIGMA TM) and placed in a growth chamber for 5 weeks $\left(35^{\circ} \mathrm{C}\right.$ for 16 hours of light to $15^{\circ} \mathrm{C}$ for 8 hours of darkness, $90 \% \mathrm{RH}$ ). The temperature and light conditions of the growth chamber were suitable for a broad spectrum of native Sandhills species. The first week the chamber was in complete darkness, but for the following weeks a daily period of 16 hours light was utilized to allow growth of the emerging plants. Moisture was maintained with distilled water. Germinable seeds were defined as all of those germinating in both the petri dish and growth chamber trials.

\section{Greenhouse Emergence Trial}

A 15 week greenhouse seedling emergence trial was used to characterize seed germinability and species composition of the emerged seedling vegetation from the seedbank (the range of temperature and relative humidity in the greenhouse was: 18 to $42^{\circ} \mathrm{C}$ and 20 to $98 \% \mathrm{RH})$. Two macroplot subsamples $\left(3,500 \mathrm{~cm}^{3}\right)$ were prechilled in a growth chamber for 14 days at 3 to $5^{\circ} \mathrm{C}$ to break dormancy; the other macroplot subsamples were not prechilled. 
Four greenhouse nursery pots $(2,800 \mathrm{~cm} 3)$ for each macroplot subsample depth treatment combination were layered from the bottom up with about $2 \mathrm{~kg}$ of seed-free sand, $0.5 \mathrm{~kg}$ soil seedbank sample approximately $1 \mathrm{~cm}$ deep, and a thin layer of seed free sand to minimize dessication of the seedbank sample. The sand used was pre-pasteurized for 2 hours at $85^{\circ} \mathrm{C}$ in a steam aerator. Each pot was watered periodically to keep the surface moist. No fertilizer was applied. Emerged plants were marked with a color coded wire ring corresponding to one of 5,3 week periods to characterize emergence rate. Plants were removed after identification.

\section{Statistical Procedures}

To adequately test treatment effects, species (or category) had to occur in 8 or more macroplots within a year for inclusion in the statistical analysis. Restricted analysis on the 10 principal species/categories limited the population of inference; however, it does characterize the most frequently occurring species/categories. The number of seeds or seedlings counted was expressed as seeds or seedlings per volume of soil. All values were converted to $0.05 \mathrm{~m}^{3}(1 \times 1 \times 0.05 \mathrm{~m}$ deep $)$ soil volume based on a sample volume calculated from the soil bulk density $\left(1.45 \mathrm{~g} / \mathrm{cm}^{3}\right)$. The soil volume represented a reasonable germination layer for most species encountered (Young 1988).

Seed Extraction/Germination Trial.The experimental design was a completely randomized design, with 4 subsamples by depth within each macroplot. Repeated measures analysis of variance was conducted using SAS procedure General Linear Models (GLM)(SAS 1988). Since germination patterns were skewed and many totals were at or near $0 \%$, an arcsine square root transformation was performed (Anderson and McLean 1974). A simple correlation prucedure was performed to correlate number of seeds and germination percentage. A mixed model was used where depth and range condition class were treated as fixed effects. Macroplot and year were considered random effects.

Greenhouse Emergence Trial. The experimental design was a split split plot in time with treatment (unchilled and chilled) as main plot and depth as subplot, with 4 subsamples by depth within each macroplot. Repeated measures analysis of variance was run using the SAS GLM procedure (SAS 1988). The 15 weeks of measurements were grouped into 5 periods of 3 weeks each. A square root transformation was applied to the emergence data (Anderson and McLean 1974). A mixed model was assumed, using treatment, depth, and range condition class as fixed effects; macroplot and year were considered random effects.

\section{Results}

The 1989 and 1990 annual precipitation measured on site was 56 and $20 \%$ below normal (203 $\mathrm{mm}$ and $368 \mathrm{~mm}$, respectively). In 1991 precipitation was 15\% above normal through August. The potential seed production in 1989 may have been affected by water stress (140 mm precipitation compared to a normal of 382 mm through August).

\section{Seedbank Diversity}

The species composition of the seedbank did not differ $(\mathrm{P}>$ 0.10 ) among range condition classes. Data were pooled across range condition for subsequent analyses. Little similarity occurred between the botanical composition of the existing flora and the species composition of the seedbank obtained from the seed extraction/germination trial and the greenhouse emergence trial $(P<0.01)$ (Table 1). Seeds of 23 species were identified in the seed extraction/germination trial: 12 grasses, 11 forbs, and 2 genera (Carex spp. and Euphorbia spp.) (Table 1). Ten grass and 13 forb species, Schweinitz flatsedge (Cyperus schweinitzii Torr.) and 2 genera (Carex spp. and Euphorbia spp.) were identified in the greenhouse emergence trial. These included 8 species which did not occur in the seed extraction/germination trial: 2 warm season grasses and 6 forbs. Thus, the seedbank identified in this study contained 14 grass and 17 forb species, Schweinitz flatsedge and unidentified Carex spp. and Euphorbia spp.

Species with an important contribution to above-ground composition [ e.g., grass like (22\%), hairy grama (Bouteloua hirsuta Lag.) (13\%), and prairie sandreed [Calamovilfa longifolia (Hook.) Scribn.] (11\%), averaged across years had very low occurrence or were absent in the seedbank (Table 1). In contrast, throughout the 2 years of this study, for both treatment and depth, the most successful seedling emergence occurred for sand lovegrass [Eragrostis trichodes (Nutt.) Wood], Scribners panicum [Dicanthelium oligosanthes (Schult.) Gould var. scribnerianum (Nash) Gould], and sand dropseed [Sporobolus cryptandrus (Torr.) Gray]. The basal cover of these species in the aboveground vegetation was relatively low (averaged across years): 1 , 2 , and $2 \%$, respectively. Western ragweed (Ambrosia psilostachya DC.) and stiff sunflower [Helianthus rigidus (Cass.) Desf.] were the only forbs occurring in excess of $2 \%$ in the vegetation and lambsquarters and marestail were the most common seedbank species.

\section{Seedbank Quantity and Germinability}

Because of their abundances, 5 grasses \{western wheatgrass [Pascopyrum smithii (Rydb.) Love], Scribners panicum, sand lovegrass, sand dropseed, and needleandthread (Stipa comata Trin. \& Rupr.)\}, a grass like category (Carex spp. and Schweinitz flatsedge), and 4 forbs lambsquarters (Chenopodium album L.), spurge spp., woolly plantain (Plantago patagonica Jacq.), and annual eriogonum (Eriogonum annuum Nutt.)\} were analyzed for the germination trials (Table 2). Seed quantity was greater in the shallower seedbank $(0$ to $5 \mathrm{~cm}$ ) than in the deeper seedbank (15 to $20 \mathrm{~cm}$ ) for both years (Table 2). The correlation between seed number and germination percentage was consistently low $(r<$ 0.60 ), with the exception of sand dropseed in the deeper seedbank in 1991. The seed germination was low, with a range of 0 to $10 \%$ for grasses, 0 to $2 \%$ for grass-like species, and 0 to $7 \%$ for forbs (Table 2). Among perennial grasses in the 0 to $5 \mathrm{~cm}$ depth, averaged over macroplots in 1990 , Scribners panicum contributed the most (171), and needleandthread the least (51) seeds $/ 0.05 \mathrm{~m}^{3}$. Forb seed dominated the shallow seedbank (70\%), but the forb germination percentage was lower than grasses. Lambsquarters accounted for the largest number of forb seeds $\left(896 / 0.05 \mathrm{~m}^{3}\right)$, averaged across years. Lambsquarters seeds are common in Nebraska seedbanks, (particularly row-crop seedbanks) and have good seed longevity compared to those of other annuals (D. Mortensen, Department of Agronomy, University of NebraskaLincoln, personal communication). Annual eriogonum was the second most important forb species in terms of seed numbers $\left(354\right.$ seeds $/ 0.05 \mathrm{~m}^{3}$ ); seed germination for this species was $<1 \%$. Similar findings on location, quantity and germination percent- 
Table 1. Genera or species identified in the soil extraction/germination trial and the greenhouse emergence trial from the seed bank and the botanical composition of the above ground vegetation in 1990 and 1991 at the Gudmundsen Sandhills Laboratory, Whitman, Neb.

\begin{tabular}{|c|c|c|c|c|c|}
\hline \multirow{3}{*}{$\begin{array}{l}\text { Seasonality! } \\
\text { Common name }\end{array}$} & \multirow[b]{3}{*}{ Scientific name } & \multicolumn{2}{|c|}{ Trial } & & \\
\hline & & \multirow{2}{*}{$\begin{array}{l}\text { Soil extraction/ } \\
\text { Germination }\end{array}$} & \multirow{2}{*}{$\begin{array}{l}\text { Greenhouse } \\
\text { Emergence }\end{array}$} & \multicolumn{2}{|c|}{ Botanical composition } \\
\hline & & & & 1990 & 1991 \\
\hline & Grasses & & & $(\%)$ & $(\%)$ \\
\hline \multicolumn{6}{|l|}{ Warm-season } \\
\hline Hairy grama & Bouteloua hirsuta Lag. & $*$ & * & $15 \pm 17^{1}$ & $11 \pm 11$ \\
\hline Little Bluestem & Schizachyrium scoparium (Michx.) Nash & $*$ & * & $6 \pm 5$ & $7 \pm 5$ \\
\hline Prairie sandreed & Calmovilfa longifolia (Hook.) Scribn & & * & $11 \pm 6$ & $11 \pm 5$ \\
\hline Sand bluestem & Andropogon gerardii var. paucipilus (Nash) Fern. & & * & $7 \pm 6$ & $6 \pm 3$ \\
\hline Sand dropseed & Sporobolus crytandrus (Torr.) Gray & $*$ & * & $4 \pm 3$ & $1 \pm 1$ \\
\hline Sand lovegrass & Eragrostis trichodes (Nutt.) Wood & $*$ & * & $1 \pm 2$ & $\mathrm{~T}^{2}$ \\
\hline $\begin{array}{l}\text { Switchgrass } \\
\text { Cool-season }\end{array}$ & Panicum virgatum $\mathrm{L}$. & * & * & $4 \pm 4$ & $2 \pm 3$ \\
\hline Downy brome & Bromus tectorum L. & * & & $\mathrm{T}$ & -3 \\
\hline Kentucky bluegrass & Poa pratensis L. & $*$ & & $2 \pm 3$ & $1 \pm 3$ \\
\hline Needleandthread & Stipa comata Trin. \& Rupr. & $*$ & * & $3 \pm 5$ & $8 \pm 4$ \\
\hline Prairie Junegrass & Koeleria pyramidata (Lam.) Beauv. & $*$ & $*$ & $3 \pm 3$ & $2 \pm 4$ \\
\hline \multirow[t]{2}{*}{ Scribners panicum } & $\begin{array}{l}\text { Dicanthelium oligosanthes (Schult.) } \\
\text { Gould var. scribnerianum (Nash) }\end{array}$ & & & & \\
\hline & Gould & * & $*$ & $2 \pm 6$ & $2 \pm 4$ \\
\hline Sixweeks fescue & Vulpia octoflora (Walt.) Rydb. & $*$ & & $1 \pm 1$ & $3 \pm 3$ \\
\hline Western wheatgrass & Pascopyrum smithii (Rydb.) Love & * & & $\mathbf{T}$ & $\mathrm{T}$ \\
\hline \multirow[t]{2}{*}{ Total } & & 12 & 10 & $58 \pm 40$ & $53 \pm 22$ \\
\hline & Grass-like & & & & \\
\hline \multicolumn{6}{|l|}{ Cool-season } \\
\hline $\begin{array}{l}\text { Sedge spp. } \\
\text { Warm-season }\end{array}$ & Carex spp. & * & $*$ & & \\
\hline Schweinitz flatsedge & Cyperus schweinitzii Torr. & & $*$ & & \\
\hline \multirow[t]{2}{*}{ Total } & & 1 & 2 & $22 \pm 12$ & $22 \pm 12$ \\
\hline & Forbs & & & & \\
\hline \multicolumn{6}{|l|}{ Warm-season } \\
\hline Annual eriogonum & Eriogonum annuum Nutt. & $*$ & & $\mathbf{T}$ & $\mathrm{T}$ \\
\hline Dwarf milkweed & Ascelpias pumila (A. Gray) Vail & & $*$ & & \\
\hline Lambsquarter & Chenopodium album $\mathrm{L}$. & $*$ & $*$ & $\mathbf{T}$ & - \\
\hline Marestail & Conyza canadensis (L.) Croq.) & & * & - & - \\
\hline Prickly lettuce & Lactuca serriola $\mathrm{L}$ & $*$ & * & - & - \\
\hline Rough fleabane & Erigeron strigosus Muhl. ex. Willd. & & $*$ & - & - \\
\hline Spotted knapweed & Centaurea maculosa Lam. & & $*$ & - & - \\
\hline $\begin{array}{l}\text { Western ragweed } \\
\text { Cool-season }\end{array}$ & Ambrosia psilostachya DC. & * & * & $5 \pm 4$ & $7 \pm 7$ \\
\hline Annual sunflower & Helianthus annuus L. & $*$ & * & $\mathrm{T}$ & $\mathrm{T}$ \\
\hline $\begin{array}{l}\text { Common yellow } \\
\text { woodsorrel }\end{array}$ & Oxalis stricta L. & & $*$ & - & - \\
\hline \multirow[t]{2}{*}{ Gromwell puccoon } & Lithospermum carolinense & & & & \\
\hline & (Walt.) Mac. M. & $*$ & & $\mathbf{T}$ & - \\
\hline Pussytoes & Antennaria neglecta Greene & & * & - & $1 \pm 1$ \\
\hline Spiderwort & Tradescantia bracteata Small & $*$ & $*$ & - & - \\
\hline Spotted beebalm & Monarda pectinata Nutt. & & * & - & - \\
\hline Spurge spp. & Euphorbia spp. & $*$ & $*$ & - & - \\
\hline Virginia pepperweed & Lepidium virginicum $\mathrm{L}$. & $*$ & * & - & - \\
\hline Western yarrow & Achillea millefolium $\mathrm{L}$. & $*$ & & - & - \\
\hline \multirow{2}{*}{ Woolly plantain } & Plantago patagonica Jacq. & $*$ & $*$ & $\mathbf{T}$ & - \\
\hline & Total & 12 & 14 & $5 \pm 4$ & $8 \pm 22$ \\
\hline
\end{tabular}

$\overline{\mathrm{SD}}$

$2=$ Trace, $<1 \%$

${ }^{3}=$ Did not occur in samples

ages were reported for other grassland seedbanks (Rice 1989 , Roberts 1981).

Seed quantity in the 15 to $20 \mathrm{~cm}$ depth averaged $22 \%$ of the shallower seed bank (Table 2); lambsquarters was the most dominant species $(72 \%)$. Species number $(P<0.01)$ and seed germination percentage $(\mathrm{P}<0.01)$ were lower for the deeper versus the shallower seedbank. Sand dropseed and sand lovegrass were the most common perennial grass species identified in both seedbanks across years.

Generally, species identified in the seedbank were small-seeded. The common, large-seeded forbs such as western ragweed

and annual or perennial sunflowers (Helianthus spp) were not observed in these trials. The seeds of some annual grasses such as sixweeks fescue [Vulpia octoflora (Walt.) Rydb.] and annual bromes (Bromus spp.) were scarce and sandbur (Cenchrus spp.) did not occur in the samples.

\section{Seedling Emergence in the Greenhouse Trial}

Five perennial grasses (hairy grama, sand lovegrass, sand dropseed, prairie junegrass [Koeleria pyramidata (Lam.) Beauv.], and Scribners panicum), a grass-like category (Carex spp. and 
Table 2. Average number of seeds $/ 0.05 \mathrm{~m}^{3}$, germination (\%), correlation ( $r$ ) between number of seeds/0.05 $\mathrm{m}^{3}$ and germination percentage, and the significance level of probability $(P>F)$ for $r$ for 10 principal species identified in a shallow (0 to $5 \mathrm{~cm})$ and deep (15 to $20 \mathrm{~cm})$ seedbanks of the 12 macroplots at the Gudmundsen Sandshills Laboratory, Whitman, Neb.

\begin{tabular}{|c|c|c|c|c|c|c|c|c|}
\hline \multirow{2}{*}{$\begin{array}{l}\text { Scasonality/ } \\
\text { Species, category }\end{array}$} & \multicolumn{4}{|c|}{ Shallow $(0$ to $5 \mathrm{~cm})$} & \multicolumn{4}{|c|}{$\operatorname{Deep}(15$ to $20 \mathrm{~cm})$} \\
\hline & \multicolumn{2}{|c|}{1990} & \multicolumn{2}{|c|}{1991} & \multicolumn{2}{|c|}{1990} & \multicolumn{2}{|c|}{1991} \\
\hline & $\begin{array}{l}\text { (Seeds) } \\
\left.0.05 \mathrm{~m}^{3}\right)\end{array}$ & (\%) & $\begin{array}{c}\text { (Seeds } \\
\left.0.05 \mathrm{~m}^{3}\right)\end{array}$ & $(\%)$ & $\begin{array}{l}(\text { Seeds } \\
\left.0.05 \mathrm{~m}^{3}\right)\end{array}$ & $(\%)$ & $\begin{array}{c}(\text { Seeds/ } \\
\left.0.05 \mathrm{~m}^{3}\right)\end{array}$ & $(\%)$ \\
\hline $\begin{array}{c}\text { Grasses } \\
\text { Warm-season }\end{array}$ & & & & & & & & \\
\hline $\begin{array}{l}\text { Sand lovegrass } \\
r \\
\mathrm{P}>\mathrm{F}\end{array}$ & $\begin{array}{c}63 \\
0.036 \\
0.036\end{array}$ & 5 & $\begin{array}{c}143 \\
0.4020 \\
0.0045\end{array}$ & 3 & $\begin{array}{l}6 \\
0 \\
0\end{array}$ & 0 & $\begin{array}{c}13 \\
0.3860 \\
0.0060\end{array}$ & 2 \\
\hline $\begin{array}{l}\text { Sand dropseed } \\
\mathbf{r} \\
\mathbf{P}>\mathbf{F}\end{array}$ & $\begin{array}{c}56 \\
0.6566 \\
0.0001\end{array}$ & 6 & $\begin{array}{c}145 \\
0.5890 \\
0.0010\end{array}$ & 10 & $\begin{array}{l}16 \\
0 \\
0\end{array}$ & 0 & $\begin{array}{c}10 \\
0.9000 \\
0.0001\end{array}$ & 2 \\
\hline $\begin{array}{l}\text { Cool-season } \\
\text { Western wheatgrass } \\
\text { r } \\
\text { P > F }\end{array}$ & $\begin{array}{c}113 \\
0.4169 \\
0.0032\end{array}$ & 2 & $\begin{array}{c}151 \\
-0.020 \\
0.8500\end{array}$ & 3 & $\begin{array}{l}3 \\
0 \\
0\end{array}$ & 0 & $\begin{array}{l}3 \\
0 \\
0\end{array}$ & 0 \\
\hline $\begin{array}{l}\text { Scribners panicum } \\
\text { I } \\
\mathrm{P}>\mathrm{F}\end{array}$ & $\begin{array}{c}171 \\
0.1528 \\
0.2997\end{array}$ & 6 & $\begin{array}{l}11 \\
0 \\
0\end{array}$ & 0 & $\begin{array}{c}28 \\
0.5158 \\
0.0002\end{array}$ & 3 & $\begin{array}{l}3 \\
0 \\
0\end{array}$ & 0 \\
\hline $\begin{array}{l}\text { Needleandthread } \\
I \\
P>F\end{array}$ & $\begin{array}{c}51 \\
0.1381 \\
0.3492\end{array}$ & 2 & $\begin{array}{l}3 \\
0 \\
0\end{array}$ & 0 & $\begin{array}{c}13 \\
0 \\
0\end{array}$ & 0 & $\begin{array}{l}0 \\
0 \\
0\end{array}$ & 0 \\
\hline $\begin{array}{l}\quad \text { Grass-like } \\
\text { Carex spp and } \\
\text { Schweinitz flatsedge }\end{array}$ & 62 & 2 & 268 & 0 & 0 & 0 & 3 & 0 \\
\hline $\begin{array}{l}\mathbf{P} \\
\mathrm{P}>\mathrm{F}\end{array}$ & $\begin{array}{l}0.0896 \\
0.5447\end{array}$ & & $\begin{array}{l}0 \\
0\end{array}$ & & $\begin{array}{l}0 \\
0\end{array}$ & & $\begin{array}{l}0 \\
0\end{array}$ & \\
\hline $\begin{array}{l}\text { Forbs } \\
\text { Warm-season } \\
\text { Lambsquarters } \\
\text { r } \\
\text { P > F }\end{array}$ & $\begin{array}{c}1.055 \\
0.3714 \\
0.0093\end{array}$ & $<1$ & $\begin{array}{c}736 \\
0.1267 \\
0.3900\end{array}$ & 1 & $\begin{array}{c}308 \\
0 \\
0\end{array}$ & 0 & $\begin{array}{c}155 \\
0 \\
0\end{array}$ & 0 \\
\hline $\begin{array}{l}\text { Annual eriogonum } \\
\mathrm{r} \\
\mathrm{P}>\mathrm{F}\end{array}$ & $\begin{array}{c}462 \\
0.2964 \\
0.0408\end{array}$ & $<1$ & $\begin{array}{c}246 \\
0.2900 \\
0.0456\end{array}$ & 1 & $\begin{array}{c}35 \\
-0.055 \\
0.7124\end{array}$ & 2 & $\begin{array}{c}23 \\
0 \\
0\end{array}$ & 0 \\
\hline $\begin{array}{l}\text { Cool-season } \\
\text { Spurge spp. } \\
\text { r } \\
\text { P > F }\end{array}$ & $\begin{array}{c}95 \\
0.1124 \\
0.4469\end{array}$ & 3 & $\begin{array}{c}96 \\
0.0429 \\
0.7721\end{array}$ & $<1$ & $\begin{array}{c}19 \\
0 \\
0\end{array}$ & 0 & $\begin{array}{l}6 \\
0 \\
0\end{array}$ & 0 \\
\hline $\begin{array}{l}\text { Woolly plantain } \\
\mathrm{r} \\
\mathrm{P}>\mathrm{F}\end{array}$ & $\begin{array}{c}62 \\
0.5942 \\
0.0001\end{array}$ & 6 & $\begin{array}{c}116 \\
0.3770 \\
0.0082\end{array}$ & 7 & $\begin{array}{c}3 \\
-0.021 \\
0.8847\end{array}$ & 6 & $\begin{array}{l}0 \\
0 \\
0\end{array}$ & $\mathbf{0}$ \\
\hline
\end{tabular}

Schweinitz flatsedge), and 4 forbs (marestail [Conyza canadensis (L.) Cronq.], rough fleabane (Erigeron strigosus Muhl. Ex Willd.), spurge spp., and woolly plantain \} were included in the analysis.

Unchilled Seeds. Total seedling emergence, averaged over 12 macroplots in the greenhouse trial from the 1990 shallow seedbank was $80 \%$ lower than in 1991 (Table 3). Grasses represented $76 \%$ of the total emergence. Grass-like species were not present. The largest number of seeds of grasses germinated between weeks 4 to 6 and accounted for 35\% of the grass emergence (11 out of 41 seedlings $/ 0.05 \mathrm{~m}^{3}$ ). Sand dropseed and sand lovegrass were the prominent grass seedlings identified. Marestail was the only forb species present and $80 \%$ of the emergence of this species occurred between weeks 7 to 9 . The total number of seedlings that emerged from the deeper seedbank (15 to $20 \mathrm{~cm}$ ) collected in 1990 was low. Marestail contributed $75 \%$ of the total. Sedges were not present and only 2 perennial grass species emerged (sand dropseed and sand lovegrass).

More grass seedlings emerged from the 1991 shallower seedbank $(\mathrm{P}<0.01)$ compared to 1990 while sedge and forb emergence was unchanged ( $P>0.42$ and 0.22 , respectively) (Table 3 ). The total number of plants that emerged was 5.4 times greater in 1991 than in 1990 . These results illustrated the annual variability of the seedbank. About $65 \%$ of the perennial grass emergence in 1991 occurred in the first 3 weeks. In 1991 the contribution of sand dropseed was larger than in 1990 , representing $67 \%$ of the total number of emerged seedlings. Forbs comprised only $6 \%$ of the total seedling emergence, emerging later, normally between weeks 7 to 9 . Grass-like species exhibited a bimodal pattern of emergence consistent with their seasonality: during the first period ( 1 to 3 weeks) and later during the fifth period (12 to 15 weeks). 
Table 3. Average seedling emergence (plants $/ 0.05 \mathrm{~m}^{3}$ ) and main effect comparisons $(P>F)$ determined in a greenhouse trial of selected species from a seedbank at 2 depths (0 to 5 and 15 to $20 \mathrm{~cm}$ depth), with 2 treatments (unchilled and chilled seeds) collected at the Gundmundsen Sandhills Laboratory in 1990 and 1991 from a sands range site. Seedling emergence was measured during a 15 week greenhouse trial. Weeks were grouped in 5 periods of 3 weeks each.

\begin{tabular}{lccccc}
\hline \hline Species/categories & Week & Week & Week & Weck & Week \\
Seedbank & $1-3$ & $4-6$ & $7-9$ & $10-12$ & $13-15$ \\
\hline
\end{tabular}

Unchilled

Shallow seedbank (0 to $5 \mathrm{~cm}) 1990$

Scribners panicum

Sand lovegrass

Sand dropseed

Marestail

TOTAL

Shallow seedbank (0 to $5 \mathrm{~cm}$ ) 1991

Scribners panicum

Sand lovegrass

Prairie junegrass

Sand dropseed

Sedges

Marestail

Woolly plantain

TOTAL

Deep seedbank $(15$ to $20 \mathrm{~cm}) 1990$

Sand lovegrass

Sand dropseed

Marestail

TOTAL.

Deep seedbank (15 to $20 \mathrm{~cm}$ ) 1991

Scribners panicum

Sand dropseed

TOTAL

Chilled

Shallow seedbank (0 to $5 \mathrm{~cm}$ ) 1990

Hairy grama

Scribners panicum

Sand lovegrass

Prairie Junegrass

Sand dropseed

Sedges

Marestail

Rough fleabane

Spurge

Woolly plantain

TOTAL

Shallow seedbank (0 to $5 \mathrm{~cm}$ ) 1991

Hairy grama

Scribners panicum

Sand lovegrass

Prairie Junegrass

Sand dropseed

Sedges

Marestail

Spurge

Woolly plantain

TOTAL

Deep seedbank (15 to $20 \mathrm{~cm}$ ) 1990

Scribners panicum

Sand lovegrass

Sand dropseed

Sedges

Marestail

Rough fleabane

TOTAL

Deep seedbank (15 to $20 \mathrm{~cm}$ ) 1991

Hairy grama

Sand lovegrass

Sand dropseed

TOTAL

(Continued on page 61) 


\begin{tabular}{|c|c|c|c|c|c|}
\hline $\begin{array}{l}\text { Species/categories } \\
\text { Seedbank }\end{array}$ & $\begin{array}{c}\text { Week } \\
1-3\end{array}$ & $\begin{array}{c}\text { Week } \\
4-6\end{array}$ & $\begin{array}{c}\text { Week } \\
7-9\end{array}$ & $\begin{array}{l}\text { Week } \\
10-12\end{array}$ & $\begin{array}{l}\text { Week } \\
13-15\end{array}$ \\
\hline & \multicolumn{5}{|c|}{ Main Effect Comparisons } \\
\hline & Grasses & & Grass-like & & Forbs \\
\hline \multicolumn{6}{|l|}{ Year } \\
\hline 1990 & 40 & & 21 & & 14 \\
\hline 1991 & 102 & & 12 & & 10 \\
\hline$P>F$ & 0.0023 & & 0.4241 & & 0.1758 \\
\hline \multicolumn{6}{|l|}{ Depth } \\
\hline 0 to $5 \mathrm{~cm}$ & 137 & & 32 & & 19 \\
\hline 10 to $15 \mathrm{~cm}$ & 5 & & 1 & & 5 \\
\hline$P>F$ & 0.0007 & & 0.0001 & & 0.0081 \\
\hline \multicolumn{6}{|l|}{ Treatment } \\
\hline Chilled & 87 & & 27 & & 16 \\
\hline Unchilled & 55 & & 6 & & 8 \\
\hline$P>F$ & 0.0058 & & 0.0024 & & 0.006 \\
\hline
\end{tabular}

Chilled Seeds. The seedbank contained dormant seed. Chilling increased seedling emergence for grasses $(P<0.01)$, grass-like species $(P<0.01)$, and forbs $(P<0.01)$, averaged across year and depth (Table 3). Chilling also increased the number of species that emerged. The difference in seedling emergence between years was smaller than for the unchilled treatment. Sand dropseed was the most abundant species to emerge in both years at both depths with chilling. Marestail was the most abundant forb.

\section{Discussion}

In this study, the seedbank was dominated by seeds of lambsquarters and annual eriogonum, both annual forbs. Aboveground vegetation, however, was dominated by perennial warmseason grasses ( $51 \%$ of the vegetation). A lack of similarity between the species composition of above-ground vegetation and the species composition of the seedbank supports results of earlier research in this biome (Louda 1989, Rice 1989, Johnston et al. 1969); however, Henderson et al. (1988) documented strong similarities between seedbank species composition and above-ground composition in desert vegetation. Rice (1989) determined that the amount of above-ground vegetation was dissimilar to the number of seeds in the seedbank, and the emergence population was proportionately different from the seed population in the seedbank.

Knowledge of the seedbank dynamics of species that make up a community can provide an understanding of important limiting factors or processes that occur within that community (Leck et al. 1989). A seedbank conserves genetic variability. Templeton and Levin (1979) stated that seeds in a seedbank provide a population with a "memory" of the selective conditions that prevailed in the past as well as more recent conditions. Rice (1989) determined that the Tallgrass Prairie of Missouri had 24 species identified in the seedbank, and the Mixed grass Prairie of Kansas had 21. The total number of germinable seeds $/ \mathrm{m}^{2}$ in the seedbank varied from 406 to 6,368 in the Mixed-grass and Tallgrass Prairie, respectively (Rice 1989). Rabinowitz and Rapp (1980) reported 30 species in the seed rain of a tall grass prairie in Missouri.

There was extensive seed damage observed in the seed census across all samples, which suggested that the seedbank was altered significantly by seed predation. Thompson (1987) suggested that the minute size of seeds in the majority of species forming persis- tent seed banks in perennial vegetation is the result of the preference for large food sources exhibited by many seed eaters. The greater presence of sand lovegrass (indicative of high seral stage) was possibly a result of its relatively small seed, which would minimize seed predation (Thompson 1987).

The limited forb emergence was unexpected, based on previous literature and the seedbank size. Apparently, the survival (considering seed predation) of many of the forb seeds was relatively short and/or there had been relatively small numbers contributed by recent seed rain. Previous Nebraska research indicated that seeds of annual weed-species were generally short-lived as compared to biennial and perennial weed seeds. Downy brome had little seed carry-over from one year to the next; however, lambsquarters seeds presented a longer carryover in a Nebraska study (D. Mortensen, Department of Agronomy, University of Nebraska-Lincoln, personal communication). West and Durham (1991) reported decreased seed rain during drier years. During this study higher precipitation in 1990, particularly in May and June, may have resulted in a higher germinable seed yield and greater seed rain compared to 1989.

A high percentage of temperate zone species have some seed dormancy, and many seeds in buried seedbanks exhibit annual (Baskin and Baskin 1989) and seasonal (Karssen 1980) dormancy/nondormancy cycles. Assuming that there had been at least 1 winter of after-ripening, the improvement in emergence and/or germination as a result of prechilling was consistent with the data of Baskin and Baskin (1989).

The low number of annuals and the relative abundance of perennial grass seedling emergence in this study do not support traditional successional theory. Among perennial grasses, sand dropseed was the most abundant species that emerged in either year or from either depth. Sand dropseed exhibits a temporal dispersal/colonization strategy (Rice 1989), and creates extensive seed reserves in the soil (up to 20,000 seeds $/ \mathrm{m}^{2}$ ) following invasion after disturbance (Lippert and Hopkins 1950). Sand dropseed, while low in percent cover $(<1 \%)$, contributed a significant number of seeds to seed rain $(50 \%)$ at other Sandhills sites (Potvin 1988). Sand dropseed, Scribners panicum, and sand lovegrass would be important in secondary succession because they emerged during the first 3 weeks in the greenhouse trial. Scribners panicum appeared to be the cool-season analogue of sand dropseed. 
Forbs emerged mostly in the last 3 weeks of the trial. The major forbs were woolly plantain and marestail. This is consistent with observations on ahandoned Sandhills cropland 1 year after seedbed preparation (King 1987). The pattern of emergence emphasized the competitive advantage of sand dropseed, since it consistently emerged prior to other species, including forbs.

\section{Conclusions}

Above-ground botanical composition and range condition were not correlated with $(P>0.10)$ seedbank species composition. Fourteen grass species, 17 forb species, and Schweinitz flatsedge were identified in the seed bank. Two additional genera (Carex and Euphorbia) also occurred in the seedbank. The composition of the seedbank exhibited yearly variation that was consistent with variability in annual precipitation, as well as rapid turnover rates and relatively high losses. More germinable seeds occurred in the 0 to $5 \mathrm{~cm}$ depth $(\mathrm{P}<0.01)$ than the 15 to $20 \mathrm{~cm}$ depth. Also, the species diversity and seed number were greater in the shallower depth. The prechilling treatment increased germination percentage for most species, suggesting that many seeds of the Nebraska Sandhills Prairie are dormant. Prechilling also increased seedling emergence of grasses $(P<0.01)$, forbs $(P<$ 0.01 ), and grass-like species $(P<0.01)$.

Germination percentage was low for all species/categories with sand dropseed having the highest (10\%). Lambsquarters and annual eriogonum had the largest seedbanks, but germination was less than $6 \%$. Sand dropseed and sand lovegrass were the most abundant perennial grasses and accounted for about $60 \%$ of germinated seeds. Perennial grasses emerged first, forbs later, and grass-like species exhibited a bimodal emergence pattern. Based on seedbank quantity, germination percentage and emergence data, sand dropseed has the potential to colonize openings in the Sandhills prairie, possibly to the exclusion of many annuals occurring in the seedbank.

\section{Literature Cited}

Anderson, V.L. and R.A. McLean. 1974. Design of experiments. A realistic approach. Marcel Dekker Inc., New York and Basel.

Baker, H.G. 1989. Some aspects of the natural history of seed banks, p. 9-21. In: M.A. Leck, V.T. Parker, and R.L. Simpson (eds.), Ecology of soil seed banks. Acad. Press, Inc., San Diego, Calif.

Baskin, J.M. and C.C.Baskin. 1989. Physiology of dormancy and germination in relation to seed bank ecology, p. 53-66. In: M.A. Leck, V.T. Parker, and R.L. Simpson (eds.), Ecology of soil seed banks. Acad. Press, Inc., San Diego, Calif.

Henderson, C.B., K.E. Petersen, and R.A. Redak. 1988. Spatial and temporal patterns in the seed bank and vegetation of a desert grassland community. J. Ecol. 76:717-728.

Johnston, A., S. Smoliak, and P.W. Stringer. 1969. Viable species populations in Alberta prairie topsoils. Can. J. Plant Sci. 49:75-82.

Karssen, C.M. 1980. Patterns of changes in dormancy during burial of seed in soil. Israel J. Bot. 29:65-73.

King, M.A. 1987. Establishment of forage grasses on abandoned Sandhills cropland. M.S. Thesis, Univ. Nebraska, Lincoln, Neb.

Kuzila, M. 1990. Soil associations and series, p 58-66. In: Ann Bleed and Charles Flowerday (eds.), An atlas of the Sand Hills. Univ. Nebraska-Lincoln, Conserv. and Survey Div. Resource Atlas No. 5a. Lincoln, Neb.
Kropac, Z. 1966. Estimation of weed seeds in arable soil. Pedobiologica 6:105-128.

Leck, M.A., V.T. Parker, and R.L. Simpson. 1989. Ecology of soil seed banks. Acad. Press, Inc., San Diego, Calif.

Lippert, R.D. and H.H. Hopkins. 1950. Study of viable seeds in various habitats in mixed prairies. Trans. Kans. Acad. Sci. 53:355364.

Louda, S.M. 1989. Predation in the dynamics of seed regeneration, p.25-51. In: M.A. Leck, V.T. Parker and, R.L. Simpson (eds.), Ecology of soil seed banks. Acad. Press, Inc., San Diego, Calif.

Maxon, S. 1993. Rules for testing seeds. Assoc. Official Seed Analysts. J. Seed Tech. 16:15-22.

McDonald, W., R. Danielson, J. Gutormson. 1992. Seed analyst training manual. Assoc. Official Seed Analysts

Nichols, J.T., P.N. Jensen, and J.L. Stubbendieck. 1984. Range judging handbook for Nebraska. Nebraska Coop. Ext. Scrv. EC 84-109. Lincoln, Neb.

Owensby, C.E. 1973. Modified step-point system for botanical composition and basal cover estimates. J. Range Manage. 26:302-303.

Pérez, C.J. 1991. Seedbank characteristics of the Nebraska Sandhills Prairie. M.S. Thesis, Univ. Nebraska, Lincoln, Neb.

Potvin, M.A. 1988. Seed rain on a Nebraska Sandhills Prairie. Prairie Nat. 20:81-89.

Rabinowitz, D. and J. Rapp. 1980. Seed rain in a North American tall grass prairie. J. Appl. Ecol. 17:793 802.

Rice, K.J. 1989. Impacts of seed banks on grassland community structure and population dynamics, p.211-230. In: M.A. Leck, V.T. Parker, and R.L. Simpson (eds.), Ecology of soil seed banks. Acad. Press, Inc., San Diego, Calif.

Roberts, H.A. 1981. Seed banks in soil. Adv. Appl. Biol. 6:1-55.

SAS Institute Inc. 1988. SAS/STAT User's Guide, Release 6.03 Ed. SAS Institute Inc. Cary, N.C.

Templeton, A.R. and D.A. Levin. 1979. Evolutionary consequences of seed pools. Amer. Nat. 114:232-249.

Thompson, K. 1987. Seeds and seed banks. New Phytol. 106, Suppl. 23-34.

Thompson, K. and J.P. Grime. 1979. Seasonal variaton in the seed banks of herbaceous species in ten contrasting habitats. J. Ecol. 67:893-921.

USDA-SCS. 1977. Soil Survey of Arthur and Grant Counties, Nebraska. Washington, D.C. U.S. Government Printing Office, Washington D.C.

West, N.E. and S. Durham. 1991. Seed rain on and near a coal stripmine in southwestern Wyoming, p. 573-582. In: W.R. Oaks and J. Bowden (eds.), Proc. 1991 Nat. Meeting Amer. Soc. Surface Mining and Reclamation. Amer. Soc. Surface Mining and Reclam. Princeton, W.Va.

Young, J.A. 1988. Seedbeds as selective factors in the species composition of rangeland communities, p.171-188. In: P.T. Teuller (ed.), Vegetation science applications for rangeland analysis and management. Kluwer Acad. Publ. Dordrecht-Boston-London. 